\title{
AOR
}

Selected Papers of \#AolR2021:

The 22nd Annual Conference of the

Association of Internet Researchers

Virtual Event / 13-16 Oct 2021

\section{"Climate Justice is Racial Justice": The Youth Climate Movement and Intersectional Media Organizing in an Algorithmic Society}

\author{
Ashley Lee \\ Study Context and Rationale
}

Before the Covid-19 pandemic struck, the world saw unprecedented levels of youth mobilization. From Black Lives Matter to March for Our Lives to the Youth Climate Strikes, the past decade saw young people leveraging social media to build movements around the world. Existing studies have shown how young people use social media to build movements in liberal democracies under the conditions of free assembly and association (Bennett \& Segerberg, 2012; Cohen \& Kahne, 2012; Jenkins et al., 2016; Literat \& Kligler-Vilenchik, 2018). However, since the global pandemic hit, young people (and others) have had to face various constraints to street mobilization and freedom of assembly. Plans to organize and take part in mass, in-person demonstrations rapidly came to a halt.

During the pandemic, the context in which youth organizers and their movements operate shifted dramatically. As youth movements come to depend heavily on the digital space, social media platforms and their algorithms may further complicate young people's ability to exercise political power. Social media platforms like Facebook, Twitter, and Tik Tok are commercial spaces where powerful actors vie for political attention (Noble, 2018). Using the broader youth climate movement as a case study, I examine how youth movements shift their tactics in response to the pandemic, and what the implications of shifting to the digital space are for the youth climate movement.

\section{Research Questions}

This study asks the following inter-related questions:

- How do young climate activists and their movement leverage social media to organize during a major health crisis?

- As youth organizing come to rely more on the digital space, what challenges do platforms and algorithms introduce for youth climate activists?

\section{Methods}

This study draws on in-depth interviews with 23 youth climate activists, along with digital ethnography and surveys that I conducted between 2019 and 2021. I used 
purposive sampling, targeting diverse youth, ages 18-30, who leverage social media to engage in youth climate activism. Each interview is 90-120 minutes in length. The interviews and surveys were conducted after obtaining informed consent from the participants. With permission from the participants, the interviews were recorded with a digital audio recorder and transcribed in full, using speech recognition software. During the interview, participants were invited to share and talk about social media artifacts they created as part of their activism. The survey included items about the respondents' present and past civic and political activities (both online and offline), as well as values, motivations, attitudes, and beliefs that underlie their participation patterns. In addition, public strategy documents that the youth climate movement produced were analyzed.

Data collection and analysis took place in tandem, and analytical strategies were modified as new data and analyses became available. In line with the analytical strategy of the grounded theory, I developed coding categories inductively and refined them in parallel with data analysis (Charmaz, 2006).

\section{Findings and Discussion}

In response to lockdown measures and other restrictions to public assembly, youth activists had to pivot away from traditional physical forms of protests, such as mass demonstrations, rallies, protests, and sit-ins. However, for young climate activists, staying apart did not mean staying silent. Instead of giving up, these young climate activists galvanized digital platforms to take actions appropriate for the moment. Young activists quickly leveraged digital platforms such as Zoom, Facebook, and Tik Tok to build foundational skills and relationships. For instance, they organized online teach-ins and skills building workshops for newcomers and members; they ramped up online fundraising; they held sessions to process grief together; they organized with local mutual aid groups; they engaged in digital storytelling in solidarity with one another.

At the same time, intersectional media organizing became front and center during the pandemic. Embracing intersectionality (Crenshaw, 1991), youth climate organizers and their movement used social media to bring into focus the voices and struggles of marginalized communities. Prior to the pandemic, even before the George Floyd protests came into focus in the summer of 2020, many young activists were approaching their climate activism as a struggle against racial injustice and other intersecting forms of oppression. When George Floyd protests broke out, young climate organizers centered racial justice in their strategies for climate justice activism. Finally, as youth organizing came to rely more on the digital space, youth activists and their movement saw the need to scale up their digital organizing infrastructure. However, inequalities introduced by social media platforms and algorithms became more acute for the youth climate movement.

In addition to my empirical findings, I will also discuss methodological considerations that came up in my study. In particular, I consider the ways in which the global pandemic has altered the terrain of field work, forcing researchers to adapt rapidly to digital methods for collecting and analyzing data. I discuss the significance of this transformation in the research landscape for analyzing and interpreting data. 


\section{Bibliography}

Bennett, W. L. \& Segerberg, A. (2012). The logic of connective action. Information, Communication \& Society, 15(5): 739-768.

Charmaz, K. (2006). Constructing grounded theory: A practical guide through qualitative analysis. Thousand Oaks, CA: Sage.

Cohen, C., \& Kahne, J. (2012). Participatory politics: New media and youth political action. Oakland, CA: MacArthur Research Network on Youth \& Participatory Politics. Retrieved from http://ypp.dmlcentral.net/sites/all/files/publications/YPP_Survey_Report_FULL .pdf

Crenshaw, K. W. (1991). Mapping the margins: Intersectionality, identity politics, and violence against women of color. Stanford Law Review, 43(6), 1241-1299.

Jenkins, H., Shresthova, S., Gamber-Thompson, L., Kligler-Vilenchik, N., \& Zimmerman, A. (2016). By any media necessary: The new youth activism. New York, NY: NYU Press.

Literat, I. \& Kligler-Vilenchik, N. (2018). Youth online political expression in nonpolitical spaces. Learning, Media \& Technology 43(4): 400-417.

Noble, S. (2018). Algorithms of oppression: How search engines reinforce racism. New York, NY: NYU Press. 